\title{
Dissemination of ICT-Based Learning Models to Improve Student Learning Independence in Higher Education
}

\author{
D Dumiyati ${ }^{1}$, A Wardhono ${ }^{2}$ and E Nurfalah ${ }^{3}$ \\ Economic Education, Universitas PGRI Ronggolawe, Tuban - Indonesia ${ }^{1}$, English Language \\ Education, Universitas PGRI Ronggolawe, Tuban - Indonesia ${ }^{2}$, Mathematics Education, \\ Universitas PGRI Ronggolawe, Tuban - Indonesia ${ }^{3}$
}

\{dumiyati@unirow.ac.id\}

\begin{abstract}
The industrial revolution 4.0 era have encouraged higher education to continuously make changes by using ICT-based learning. In the previous year a validity test on the ICT-based learning model was conducted. For a broader application, dissemination and testing should be implemented by other universities, specifically by Muhammadiyah University Gresik. The research results are the lecturers ability to apply of ICT-based learning model syntaxs in high cathegory. The student response to the application of ICT-based learning models, audiobook media and excercise i-Spring quizzes are effective and helpful in improving learning activities, result and student learning independence.
\end{abstract}

Keywords: ICT-Based, learning models, learning independence, higher education.

\section{Introduction}

This research is motivated by the difficulty of studying English for Specific Purposes (ESP) experienced by students in tertiary institutions. Based on previous research conducted by [1], several obstacles were encountered in teacher-centred ESP lectures, among others: students had difficulty reviewing the material, limitations of communication and discussion forums outside face-to-face lectures, limited multimedia learning, activities and low learning independence. In a rapidly changing of the science and technology, students must be able to adapt to learn new skills and permanently improve their competencies. Learning independence must be a lifestyle. Learning independence includes: problem solving skills, interpersonal skills, self-motivation, creativity, being reflective [2], [3]. According to [4] said the independence of student learning is the extent to which students can participate in determining the objectives, materials and learning experiences and evaluation of learning. And students who are already very independent have the following characteristics: know what they want to achieve in their learning activities, can choose their own learning resources, can find sources to help their learning difficulties, try to solve problems, can assess their ability.

From the results of needs assessment through a survey of lecturers and students, $83.3 \%$ of the lecturers wanted to implement Information and Communications Technology (ICT) based learning innovations, as many as $73.7 \%$ of students were interested in online lectures and $26.3 \%$ were more interested in face-to-face lectures, $50 \%$ of students felt interesting lecture 
media could motivate the learning process, and $65 \%$ of students stated that the unavailability of online learning material and online evaluation facilities caused low learning independence [5]. This statement reinforces the reason for researchers to develop ICT-based learning models with e-book media as supporting e-learning [6]. In the ICT learning model, teaching materials are presented in the form of online materials (e-books). But e-book media can cause boredom and eyestrain when perused for a long time. According to [7] one of the effects of digital books is fixation on computer screens, tablets, or cell phones when reading digital books. This results in students being less concerned about the environment and social interactions, becoming susceptible to computer vision syndrome [8].

To overcome the weaknesses of the e-book, an audiobook media was developed to complement online material and evaluation using the i-spring quiz because in the digital era and industrial revolution 4.0, it has improved higher education to make changes continuously by using ICT-based learning. According to [9], [10]; This media can help students to think well, foster memory and sharpen hearing. [11] said that audiobook media was widely enjoyed because with audiobooks, students could understand the contents of books without having to read, just by listening to them on a car tape, at home, or while traveling while doing other activities. Audiobooks can be developed as supporting media for ICT-based learning. The research results of [12] confirmed the implementation of ICT in the teaching-learning process is strictly speaking learning by actively seeking one's own information. Strengthened by the opinion of [13], ICT is any technology that students and teachers use to create, find, collaborate modify, analyze, evaluate and disseminate information. While [14] the use of interesting media in ICT-based learning can make learning more directed, enjoyable and meaningful. This statement is strengthened by [15] The development of information technology and computers that are very rapid lately, is received a positive response in community since various services have implemented ICT.

Based on the arguments above, research on developing ICT-based learning models with audiobook media and I-spring quizzes is expected to be a solution to help students understand ESP material and improve learning activities and build learning independence. Trials testing the application of ICT-based learning models with audiobook media were carried out at Muhammadiyah University (Unmuh) Gresik and PGRI University Ronggolawe (Unirow) Tuban. This paper poses three research questions:

a) How the lecturers ability to apply of ICT-based learning model syntaxs?

b) What is the effectiveness of e-book media, audiobooks and I-spring quizzes as supporters in ICT-based learning?

c) How the effectiveness of e-book, audiobook, I-spring quizzes in increasing learning independence based on student responses?

\section{Research method}

\subsection{Type of Research}

This type of research including development research refers to [16] as follows: (1) initial assessment phase, (2) design, (3) realization / construct, (4) test/evaluation and (5) implementation phase. This research was conducted for a period of 3 years. In the first year (2017) the initial assessment, needs analysis, model development and model support tools were carried out as well as validity testing. In the second year (2018) there was a testing / evaluation and revision phase through trials at PGRI University Ronggolawe Tuban. In the 
third year (2019) the implementation phase was carried out by a large-scale trial at the University of PGRI Ronggolawe Tuban (Campus A) and at another university, namely Muhammadiyah University Gresik (Campus B).

\subsection{Research Subject}

The research subjects included all students of the Management and Accounting Study Program of Muhammadiyah University Gresik in Semester 2 amounting to 36 and students of the English Language Study Program in Semester 2 of PGRI University Ronggolawe Tuban amounting to 36, along with 2 ESP lecturers from both universities. Data collection techniques used observation, questionnaires and quizzes/test.

\subsection{Data Analysis}

Three methods have been used to measure the effectiveness of the application of ICTbased learning models:

\section{a) Analyzing the ability of lecturers to implement ICT-based learning syntax}

Observations were made on the lectures ability (LA) to manage each phase in the model syntax. From the results of the evaluation of the two observers, the average LA values of LA1 and LA2 with LA1 $=$ the mean value of the results of the first observer assessment and LA2 = the average value of the results of the second observer assessment. The LA value is then confirmed by the interval in determining the category of lecturers' ability to manage learning, namely:

LA $<1.5$ means very low

$1.5 \leq \mathrm{LA}<2.5$ means low

$2.5 \leq \mathrm{LA}<3.5$ means enough / moderate

$3.5 \leq \mathrm{LA}<4.5$ means height

$4.5 \leq$ LA $<5.0$ means very high ability

The ability of lecturers to manage learning is said to be effective if at least the high category.

\section{b) Analyzing the pretest and posttest scores}

The data were processed by using SPSS 14.0: Descriptive statistics (mean, variance, standard deviation the two test scores)

\section{c) The other was to get student feedback}

Percentage were used to analyze the students' responses to the questionnaire. 


\section{Result and discussion}

\subsection{The ability of lecturers to apply of ICT-based learning model syntaxs}

Table 1. Description of the ability of lecturers to apply ICT-based learning syntax

\begin{tabular}{lcccc}
\hline \multicolumn{1}{c}{ Syntax } & lecturer (A) & lecturer (B) & Average & Cathegory \\
\hline Preliminary and motivation & 4,44 & 4,22 & 4,33 & High ability \\
Concept Presentation & 4,17 & 4,00 & 4,06 & High ability \\
Search for relevant learning resources & 4,50 & 4,50 & 4,50 & Very high ability \\
Interaction and communication in the & 4,17 & 4,00 & 4,08 & High ability \\
Telegram group and email & & & & \\
Guide Presentation and Discussion & 4,28 & 4,22 & 4,25 & High ability \\
Making a Summary with students & 4,00 & 4,00 & 4,00 & High ability \\
Feedback of the Evaluation test result & 4,44 & 4,44 & 4,44 & High ability \\
by email & & & & \\
\hline
\end{tabular}

Table 1 shows the ability score of lecturers (LA) in managing ICT-based learning between $4.00<\mathrm{LA}<4.50$ classified as belonging to the high category in 6 phases and the very high category in the phase of searching for relevant learning resources. The ability of lecturers is said to be effective if the minimum score reaches the high category. As revealed by [17], in institutions of Higher Education, the utilization of modern information and communication technologies for teaching and learning is very important. According to [18]-[20], mastery of ICT and its implementation in learning became an absolute potential that lecturers must possess, that is to say for developing multimedia materials, systems for implementing and evaluating programs. While [21] added that there are 3 fundamental elements of essential competence for teachers needed for effective ICT integration in the teaching and learning process, namely pedagogy, social interaction and technology. The syntax of ICT-based learning presented in table 1 is a learning activity that combines online learning (independent) and face-to-face Learning activities.

Table 2. Descriptive statistics of two test

\begin{tabular}{lcccccc}
\hline & \multicolumn{2}{c}{ Campus A } & \multicolumn{2}{c}{ Campus B } & N & N \\
\cline { 2 - 5 } & Pretest & Postest & Pretest & Posttest & (campus A) & (campus B) \\
\hline Mean & 60,278 & 85,278 & 61,945 & 85,556 & 36 & 36 \\
Standard deviation & 7,099 & 10,809 & 5,599 & 10,278 & & \\
Variance & 50,397 & 116,825 & 31,349 & 105,635 & & \\
\hline
\end{tabular}

Table 2 addresses the results of the student pretest and posttest at both universities. On campus $\mathrm{A}$ and campus B, the mean of the posttest was higher than that of the pretest. This shows that after participating in ICT-based ESP learning with e-book, audiobook media and I-Spring quizzes, students' understanding of the material (learning outcomes) has been greatly improved.

Table 3. Student feedback on the implementation of ICT based learning models

\begin{tabular}{|c|c|c|}
\hline \multicolumn{3}{|c|}{$\begin{array}{l}\text { Question: Are you statified with the implementation } \\
\text { of ICT based learning models? }\end{array}$} \\
\hline Items & $\begin{array}{c}\text { Students feedback } \\
\text { (campus A) \% }\end{array}$ & $\begin{array}{c}\text { Students feedback } \\
\text { (campus B) \% }\end{array}$ \\
\hline Very Satisfied & 38,88 & 30,55 \\
\hline
\end{tabular}




\begin{tabular}{lcc}
\hline Satisfied & 52,77 & 61,11 \\
Reasonably satisfied & 5,55 & 5,55 \\
Just so-so & 2,77 & 2,77 \\
Not so satisfied & 0,00 & 0,00 \\
\hline
\end{tabular}

As shown as table 3, the number of students who were satisfied and very satisfied $>90 \%$, showed that both students from Campus A and Campus B responded positively to the application of ICT-based learning models.

\subsection{Effectiveness the e-book, audiobook and quiz I-spring}

Table 4. Opinions on the e-book, audiobook and I-spring quizzes

\begin{tabular}{lcccccc}
\hline \multicolumn{2}{c}{ Question: Are you statified with the contents of the e-book, audiobook and quizzes? } \\
\hline \multicolumn{1}{c}{ Items } & \multicolumn{2}{c}{ Students feedback (campus A) \% } & \multicolumn{2}{c}{ Students feedback (campus B) \% } \\
\cline { 2 - 7 } & e-book & Audiobook & I-spring Quiz & e-book & Audiobook & I-spring Quiz \\
\hline Very Satisfied & 16,67 & 61,11 & 19,44 & 16,67 & 63,89 & 25,00 \\
Satisfied & 66,67 & 30,56 & 69,44 & 63,89 & 22,78 & 63,89 \\
Reasonably satisfied & 11,11 & 8,33 & 5,56 & 13,89 & 5,56 & 83,33 \\
Just so-so & 5,56 & 0 & 5,56 & 5,56 & 2,78 & 2,78 \\
Not so satisfied & 0 & 0 & 0,00 & 0 & 0 & 0,00 \\
\hline
\end{tabular}

Based on the data in table 4 shows that most students on Campus A and Campus B are satisfied with the contents of the e-book, while the content of the audiobook as supporting media in the ICT-based learning model made them feel very satisfied. Likewise, the contents of the I-spring quiz amounted to $69.44 \%$ of campus A students and $63.89 \%$ of campus B students feeling satisfied, and even $19.44 \%$ of campus A students and $25 \%$ of campus B students were very satisfied with the content of the quizzes.

Table 5. Effectiveness of the e-book and audiobook

\begin{tabular}{lcccc}
\hline \multicolumn{4}{c}{ Question: Do you think the e-book and audiobook are helpful in improving } \\
the ability to understand the subject matter?
\end{tabular}

Table 2 that has been presented previously shows an increase in posttest results compared with the pretest. The data in table 5 explains that most students on all campuses feel the ebook and audiobook are helpful in improving the ability to understand the subject matter. The ability of students to understand lecture material causes the learning outcomes to increase. This is in accordance with [22], to increase the learning outcome [23], [24] said that the use of audio is an effective strategy to improve learning outcomes and language skills, especially listening and speaking. The research results from [25]-[27] in his research revealed the effectiveness of the use of audio media can improve the quality of the learning process and learning outcomes. 


\subsection{The impact of the e-book, audiobook and I-spring quizzes to improve learning independence}

Table 6. Effectiveness The e-book and audiobook to improve learning independence

\begin{tabular}{lcccc}
\hline \multicolumn{4}{c}{$\begin{array}{c}\text { Question: Do you think the e-book and audiobook are helpful in } \\
\text { Improving the students' learning independence? }\end{array}$} \\
\hline \multicolumn{1}{c}{ Items } & \multicolumn{1}{c}{ Students feedback (campus A) \% } & Students feedback (campus B) \% \\
\cline { 2 - 5 } & e-book & Audiobook & e-book & Audiobook \\
\hline Very helpful & 41,67 & 61,11 & 44,44 & 58,33 \\
Helpful & 47,22 & 30,56 & 36,11 & 36,11 \\
Reasonably helpful & 11,11 & 8,33 & 19,44 & 5,56 \\
Not so helpful & 0,00 & 0,00 & 0,00 & 0,00 \\
Not helpful at all & 0,00 & 0,00 & 0,00 & 0,00 \\
\hline
\end{tabular}

Table 6 shows that both the use of e-books and audiobooks as supporting media for the application of ICT-based learning models is very helpful in increasing student learning independence. Through these media, students can review the lecture material outside of class hours and study the next part independently. In accordance with the functions of e-books and audiobooks, namely as an alternative learning media, presenting more interesting and enjoyable teaching materials, media for sharing information are more flexible and can be learned at any time outside of lecture hours, so that learning independence increases. The independence of student learning is an important factor in the successful application of ICTbased learning. This was revealed by [28], [29] Online learning is student-centered and requires strong self-motivation, while [30] asserts that students must be very responsible for self-study.

Table 7. Effectiveness of the quiz to do the evaluation independently

\begin{tabular}{|c|c|c|}
\hline \multicolumn{3}{|c|}{$\begin{array}{l}\text { Question: What do you think of the quizzes presented at the end of each } \\
\text { chapter to do the evaluation independently? }\end{array}$} \\
\hline Items & Students feedback (campus A) \% & Students feedback (campus B)\% \\
\hline Very helpful & 25,00 & 27,78 \\
\hline Helpful & 66,67 & 63,89 \\
\hline Reasonably helpful & 5,56 & 8,33 \\
\hline Not so helpful & 2,78 & 0,00 \\
\hline Not helpful at all & 0,00 & 0,00 \\
\hline
\end{tabular}

Table 7 shows that the quizzes presented at the end of each chapter help students independently evaluate (supported by $66.67 \%$ of the students on campus A and $63.89 \%$ of the students on Campus B. Students who think the quizzes are very helpful amount to over $25 \%$ of campus A students and $27.7 \%$ of Campus B students find quizzes very helpful in evaluating independently. The results of the study are in line with [31], [32], who observed that quizzes and self-assessment tests make students check their own learning. The assessment of quiz activities will be assessed automatically by the I-spring application system, feedback from lecturers via email and interaction and communication can be conducted through study groups with the application of giving feedback directly, which can affect effective learning and evaluation.

\section{Conclusion}

The results of data analysis show that the implementation of ICT-based learning models with e-book media, audiobooks and I-Spring quizzes are effective. Both the e-book media, 
audiobooks and I-spring quizzes as supporting devices in ICT-based learning are effective and helpful in improving learning activities, result and student learning independence.

\section{Acknowledgement}

The research team would like to express their gratitude to DRPM Kemenristekdikti for funding this research project through applied research grants.

\section{References}

[1] Dumiyati \& Wardhono, A., Nurfalah, E.: Pengembangan Perangkat Model Pembelajaran English For Specific Purpose (ESP) berbasis ICT. Prosiding SnasPPM. pp. 1-6. (2017).

[2] Boud, D. (1995). Enhancing learning through self assessment. London: Kogan Page.

[3] Barab, S., \& Plucker, J. A. (2002). Smart people or smart contexts? Cognition, ability, and talent development in an age of situated approaches to knowing and learning. Educational Psychologist, 37(3), 165-182.

[4] Keegan: Theoritical Principles of Distance Education. London \& New York:Routledge. (1991)

[5] Dumiyati \& Wardhono, A., Nurfalah, E.: Practically and Effectiveness of ICT Based Learning Models as support of e-Learning, Prosiding ICEGE, pp. 103 (2018).

[6] Dumiyati \& Wardhono, A., Nurfalah, E.: Kepraktisan dan Keefektifan Penerapan Model Pembelajaran Berbasis ICT, Jurnal JPEKA, pp. 1-14 (2019).

[7] Dipokusumo, F.: Dipokusumo, F. Buku Digital Punya Efek Negatif untuk Anak. Tempo.co. http://www.tempo.co/read/news/2014/03/02/079558739/Buku-DigitalPunya-Efek-Negatif-untuk-Anak. Diakses tanggal 19 September 2019.

[8] Info kesehatan.: Benarkah, Membaca di Perangkat Elektronik Merusak Mata? (2013). http:// www.infokesehatan.biz.id/2013/03/benarkah-membaca-diperangkat.html accessed on 14 September 2019

[9] Anwas, O.M.: Audobook Media pembelajaran Masyarakat Modern, Journal Teknodik Vol. 18 nomor 1, April 2014. Pp. 54-69 (2014)

[10] Susilana, R dan Riyana, C.: Media Pembelajaran: Hakikat, Pengembangan, Pemanfaatan dan Penilaian, CV. Wacana Prima, Bandung. (2009).

[11] Rubery, M.: Audiobooks, Literature and Sound Studies, Book. Routledge, Taylor \& Francis. (2011).

[12] Kassim, H. \& Ali, Z.: The Use of ICT in The Implementation of student Centered learning (SCL). Internet Journal of e-language Learning \& Teaching, 4 (1). pp 15-31 (2007)

[13] Asiyai, R.I.: Assessment of Information and Communication technology Integration in Institution of Higher Learning. Jounal International Education Studies. 7(2). (2014)

[14] Bandhana: Integration of Information and communication technology in Enchanching Teaching \& learning, Journal Contemporary Educational Technology, 3(2).pp.130-140. (2012)

[15] Anwar, $\mathrm{K}$ and Wardhono, A: Information and Communication Technology (ICT) in English Learning: through an Interactive Software-Website. https://www.atlantispress.com/proceedings/iconelt-17/25889000 Accessed on October 2nd, 2019. (2017)

[16] Plomp, T.: Educational and Training System Design. Enschede, The Netherlands: 
University of Twente.(1997)

[17] Arkorful, V. And Abadoo, N.: The Role of E-Learning. The Advantages and Disadvantages of its Adoption in Higher Education. International Journal of Education and Research, 2(12). (2014)

[18] Savittree, R.A., Padilla, MJ and Tunhikorn, B.: The Development of Pre service Science teacher Professional Kwonledge in Utilizing ICT to Support profesional Lives. Eurasia Journal of Mathematic Sciences and technology Education, 5(2). pp. 91-101.( 2008)

[19] Akarawang, C.: Developing ICT Competency for Thai Teachers through Blended Training. Journal of Education and Learning. Vol. 10 (1) pp. 15-21. 2016.

[20] Anwariningsih, S.H dan Ernawati, S.: Development of Interactive Media for ICT Learning at Elementary School Based on Student Self Learning. Journal of Education and Learning. Vol.7 (2) pp. 121-128. 2013.

[21] Wang, Q.; A Generic Model for Guiding The Integration of ICT Into teaching and Learning. Innovations in education and Teaching International (online).Journal. Rothledge Taylor \& Francis Group. 45 (4). Pp. 411-419. (2018).

[22] Jadal, M.M.: A Study of Effectiveness of The Audio-Visual Aids in Teaching and Learning English at Primary Level 2 Primary school of Solafur District. Indian Streams Research journal. 1(1). Pp. 1-21. (2011)

[23] Yassaei.: Using Original Video and Sound Effects to teach English. Journal in English Teaching Forum Vol 50. Pp. 12-16. (2012)

[24] Have, I. \& Pederson, BS.: Digital Audiobooks: New media, User and Experiences, Routledge. Taylor \& Francis. (2016).

[25] Sevik, M. Teacher Views about Using Songs in Teaching English to Young Learners. Journal Educational Researc and reviews, 6(21).pp. 10-27. (2012).

[26] Wicaksono, A.: Peran Media Audio dalam Meningkatkan Kualitas Proses pembelajaran Apresiasi Cerita Pendek. Jurnal Shahih, 2(1).pp. 67-78. (2017)

[27] Ratmaningsih, N.M.: Effectivitas Media Audio Pembelajaran Bahasa Inggris berbasis Lagu Kreasi di Kelas 5 SD. Jurnal Pendidikan Indonesia, 5(1). Pp. 27-38. (2016).

[28] Smart, K.L. and Chappel, J.J.: Students' Perceptions of Online Learning: A Comparative Study. Journal of Information Technology Education, 5, pp. 201219.(2006)

[29] Shukora, N.A,; Tasira, Z.; Meijdenb, H.V.D.; Haruna, J.: A Predictive Model to Evaluate Students' Cognitive Engagement in Online Learning. 5th World Conference on Educational Sciences -WCES 2013. Science Direct. Procedia - Social and Behavioral Sciences 116 ( 2014 ) pp. 4844 - 4853. (2014).

[30] Nedelko, Z.: Participants' Characteristics for E-Learning. E-Leader Conference, Krakow. (2008).

[31] Chou, P.N \& Chen, W.F.: Explanatory Studi of The Relationship between Self Directed Learning and Academic Performance in Web-based Learning Environment. Online Journal of Distance Learning Administration, XI(1). University of West Georgia, Distance Education Center. Pp.1-11. (2008)

[32] Sutarno, E \& Mukhidin: Pengembangan Model Pembelajaran berbasis Multi media Interaktif Pengukuran untuk Meningkatkan Hasil dan Kemandirian Belajar siswa. Jurnal Pendidikan Teknologi dan kejuruan. 21(3) pp. 205-218. (2013) 